\title{
Swedish rape legislation from use of force to voluntariness - critical reflections from an everyday life perspective
}

\author{
MOA BLADINI*, WANNA SVEDERG ANDERSSON**
}

'I was raised in a world where girls were taught that they get raped for a reason. Their skirt was too short, their smile was too wide, their breath smelled of alcohol. And I was guilty of all of those things, so the shame had to be mine. It took me years to realize that only one thing could have stopped me from being raped that night, and it wasn't my skirt, it wasn't my smile, it wasn't my childish trust. The only thing that could have stopped me from being raped that night is the man who raped me had he stopped himself.'

\section{Introduction}

Criminal legislation on rape has in Sweden been debated and revised several times in the last few decades. In 2018 a new construction of rape was introduced, signifying an important shift in the understanding of and responsibility for rape. The two most significant changes are the change in the construction of rape, where the decisive

* Moa Bladini, LL.D., senior lecturer at the Department of Law, Gothenburg University. This article is part of the research project Rape or Consent? Effects of the new rape laws on legal reasoning and practice. The project is funded by Riksbankens Jubileumsfond for the period 2020-2022. Email: moa.bladini@law.gu.se

** Wanna Svedberg Andersson, LL.D., senior lecturer at the Department of Law, Gothenburg University. Email: wanna.svedberg@law.gu.se. We want to express our gratitude to the anonymous reviewer and to professor Jørn Jacobsen, the editor of this journal, and research assistant, Victoria Westrum, for valuable comments on earlier drafts of this article.

1 https://www.ted.com/talks/thordis_elva_and_tom_stranger_our_story_of_rape_and_ reconciliation (accessed 27 January 2021).

This is an Open-access article distributed under the terms of the Creative Commons Attribution 3.0 Unported License (http://creativecommons.org/licenses/ by/3.0/), permitting all use, distribution, and reproduction in any medium, provided the original work is properly cited. 
criterion of use of force is replaced by a requirement of voluntariness (corresponding to lack of consent in public debate) and the new crime of negligent rape.

The overarching aim of this article is to review and critically analyse Swedish statutory regulation of rape, including previous discussions. We take our point of departure in feminist legal studies, and some of the critique that has been put forward within this field.

At the core of criminal legislation on rape we find the aim to protect the individual's right to personal and sexual integrity and sexual self-determination. ${ }^{2}$ These are the fundamental interests to be protected and have been at the centre of the discussions on the legal construction of rape for the last fifty years and are also the focus of analysis in this article. The debate, in Sweden and elsewhere, has focused mainly on two options as possible ways of constructing the rape offence, either with use of force or with consent, ${ }^{3}$ as the decisive criterion. ${ }^{4}$ To simplify, the continental countries in Europe have been stuck to a construction of the rape offence based on use of force for longer than Anglo-American countries, which introduced a concept of lack of consent earlier. ${ }^{5}$ The Nordic countries have historically had their rape legislation based on use of force. ${ }^{6}$ In Sweden, feminist activism, political debate and critical legal research finally led to extensive changes in legislation on sexual offences which entered into

2 Prop. (2017/18:177) En ny sexualbrottslagstiftning byggd på frivillighet, p. 21.

3 We use different concepts in different contexts. Consent has been the wording used in the public debate in Sweden as well as in international discourse on rape, and when addressing these general discussions, we will therefore use only consent. In comparison, when we discuss consent in the specific Swedish context, i.e. development towards current legislation based on voluntariness, we use lack of consent, which was the wording used in the terms of reference of previous sexual offences inquiries in 1998 and 2008 (SOU 1998:48, Översyn av lagstiftningen om sexualbrott and SOU 2008:94, Utvärdering av 2005 års sexualbrottsreform, m.m.). Voluntariness is used in relation to the current legislation as it became the decisive criterion.

$4 \quad$ MacKinnon, Rape Redefined, 10(2) Harvard Law \& Policy Review (2016) pp. 431-477, McGlynn \& Munro, Rethinking Rape Law: International and Comparative Perspectives (Routledge 2010) and Leijonhufvud, Samtyckesutredningen: Lagskydd för den sexuella integriteten (Thomson förlag 2008).

5 In a European context, countries have handled the discussions on and demands for consentbased legislation differently over the years. England and Wales adopted consent-based rape legislation early (in 1976), but it has proved difficult to implement in practice (Munro 2010). Scotland resisted the demands for legal change for longer, but changed its legislation about a decade ago. In continental Europe, countries such as Italy and Croatia changed their laws in the early 2000s, while the shift from use of force to consent in the debate in the Nordic countries took place around 2005. See Jokila \& Niemi, Rape Law and Coercive Circumstances in Rape in the Nordic Countries: Continuity and Change, eds. Heinskou, Skilbrei \& Stefansen (Routledge 2020) pp. 120-136, p. 122.

$6 \quad$ Jokila \& Niemi 2020 pp. 120-136. 
force in July $2018 .^{7}$

The new legislation brings an important change by clarifying that a (female) body is not available until she says 'stop', but unavailable until she says 'yes.' ${ }^{\text {' According to }}$ the preparatory works, legislation based on whether or not participation in a sexual activity is voluntary is expected to send a clear normative message that if sex is not voluntary, it is illegal. This, in turn, is assumed to influence people's values and attitudes in the long term and contribute to a view of sexual activity as a relationship that is based on reciprocity. ${ }^{9}$ We hold that the new legislation thereby meets the criticism that has long been directed at the previous legislation. However, one important aspect of feminist critique of criminal law in general, and regarding sexual violence and violence against women in particular, is the problem of the traditional understanding of the subject, in line with the liberal conception of the autonomous and rational individual. ${ }^{10}$ We argue that the criterion of voluntariness risks reinforcing this view of the subject. Feminist critique of rape legislation has argued that the construction of rape is problematic, in the sense that it lacks the ability to take into account structural perspectives, i.e. various forms of power imbalances, vulnerabilities and coercive circumstances. ${ }^{11}$ In this article we will discuss the new rape legislation, with these

7 The non-governmental organisation Fatta has had a great impact and worked closely with professor emerita Madeleine Leijonhufvud, one of the most prominent legal scholars on rape legislation in Sweden. Andersson, Burman, Svedberg and Wegerstad are also mentioned as important legal scholars who have contributed to its development. In the wider context of sexual offences, Westerstand, Sutorius and Kaldal have also made important contributions. Although the expression \#metoo was first used by Tarana Burke in 2006 to highlight, and raise awareness of, sexual harassment and assault in society, the \#metoo movement began in October 2017, when Alyssa Milano asked women across the world to reply to her tweet with the hashtag \#metoo. Her post followed allegations of a film producer in Hollywood having raped several actresses, and was intended to criticise the film industry for suppressing what had happened. In Sweden, the movement led to branch calls starting in November 2017, consisting of tens of thousands of testimonies.

8 Andersson, Hans (ord) eller hennes (Bokbox förlag 2004). We wish to highlight that this description has two normative dimensions, the one that makes women's bodies unavailable until she says yes that we welcome, but another aspect of such a formulation reproduces and consolidates the idea of active male sexuality and a female passive sexuality. (Perhaps the wording could be changed to - until she invites him.) In this context, is the symbolic value related to a discussion on the rape offence, and not in relation to sexual offences in general.

9 Prop. (2017/18:177) p. 22.

10 Andersson, Våld mot kvinnor och straffrätt in På vei: kjønn og rett $i$ Norden, eds. Svensson et al. (Makadam förlag 2011), Burman, Rethinking Rape laws in Sweden: coercion, consent or non-voluntariness? in Rethinking Rape Law. International and Comparative Perspectives, eds. McGlynn \& Munro (Routledge 2010) and Berglund, Samtycke eller ej? in Argumentation $i$ nordisk straffrätt, eds. Nordlöf (Nordstedts juridik 2013). See also Naffine, Can women be legal persons? in Visible women: Essays on feminist legal theory and political philosophy, eds. James \& Palmer (Hart 2002) pp. 150-173 and Niemi, What we talk about when we talk about buying sex, 16(2) Violence Against women (2010) pp. 159-172.

$11 \quad$ Andersson 2010 \& Jokila \& Niemi 2020. 
critical stances as a backdrop.

The new voluntariness-based construction of the rape offence aims to strengthen personal and sexual integrity and sexual self-determination. Some crucial issues remain however unaddressed in the preparatory legislative process and need to be reflected upon. The first issue is the assumption of what the interests to be protected are and the second is how they are best protected. These questions need to be scrutinised from an everyday life perspective. We examine whose knowledge and whose experiences are used in the legislative process and what it means for those who are meant to be protected.

The article starts with a brief historical overview of the legislative process, from 1998 until the current rape legislation that will be examined in greater depth. This is followed by a discussion of the new criterion of voluntariness through the lens of autonomy. The article ends with some concluding comments and reflections on future challenges and research questions. ${ }^{12}$

\section{How we got here - from violence and threats, through lack of consent towards voluntariness ... and beyond}

\subsection{Introduction}

This section is intended to provide a brief historical overview of the legislative process. Below, we will use the word 'process' when referring to the development of rape legislation, i.e. from the use of force (violence and coercion) construction as the decisive criterion of rape, through a discussion of lack of consent, to current rape legislation based on voluntariness. ${ }^{13}$ In this process we wish to highlight the most important changes regarding the definition of rape related to the previous rape legislation based on use of force.

We start by illustrating the process and the changes to rape legislation with a timeline, as this can facilitate an understanding of the legal reforms and their chronological sequences regarding changes in the legal definition of rape. Our intention is not to present a comprehensive description of all the changes, but to focus on certain discussions and changes essential for our discussion later on.

12 This article can be read as a whole, but those interested only in the historical development of rape legislation in Sweden can read chapters 1-3 (chapter 2 gives a historical overview and chapter 3 deals with the present-day legislation). For those with a particular interest in challenges of present-day legislation, discussed from an everyday life perspective, we recommend reading chapter 4 in particular.

13 The focus will be on the period 1998-2018, see Figure 1 below. 


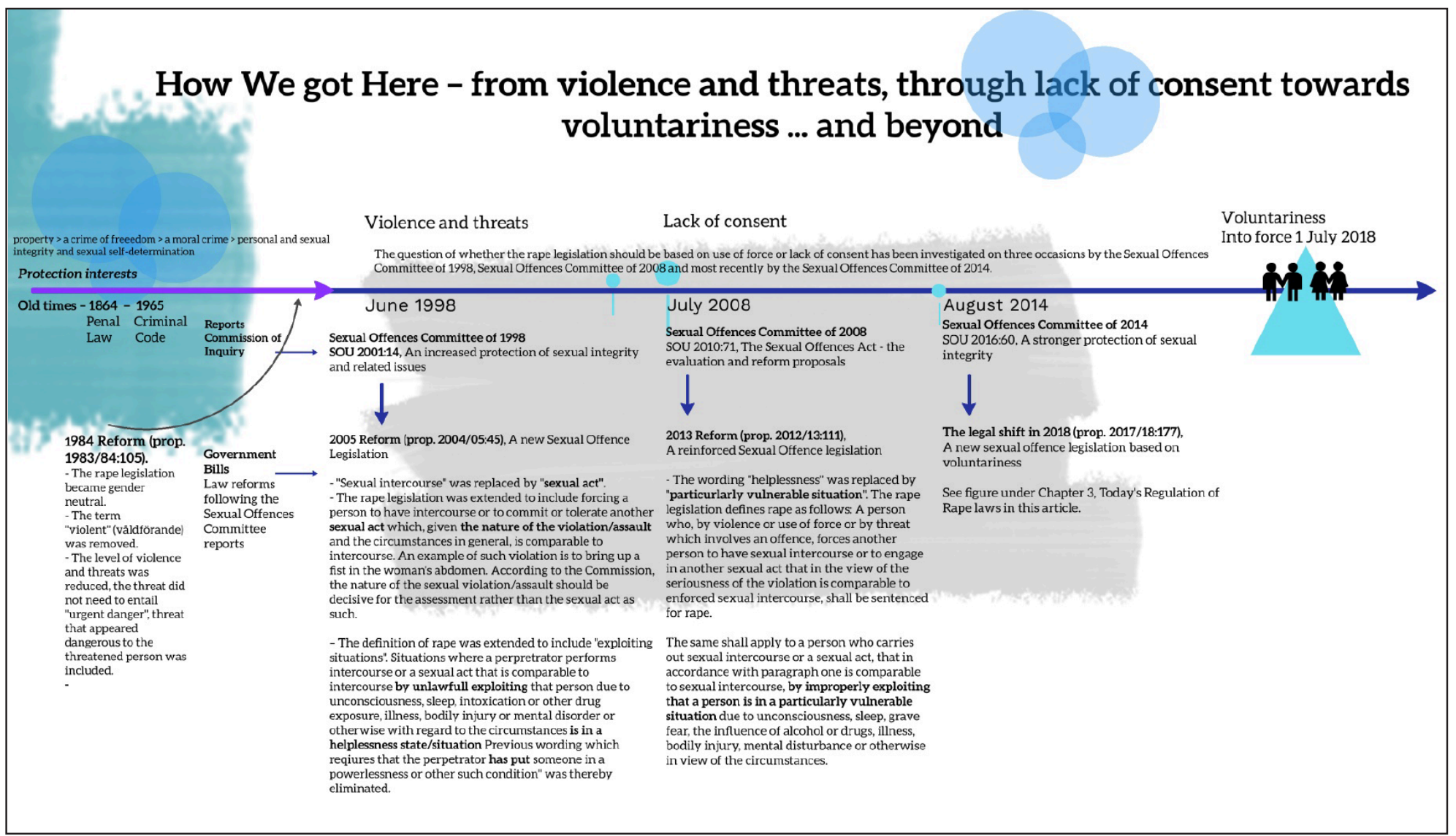

Figure 1. The figure gives a simplified overview of the development of rape legislation, i.e. from the use of force (violence and coercion) construction as the decisive criterion of rape, through a discussion of lack of consent, that started in 1998, to current rape legislation based on voluntariness.

The question of whether the rape legislation should be based on use of force or lack of consent has been investigated on three occasions, by the Sexual Offences Committee of 1998, the Sexual Offences Committee of 2008, and most recently the Sexual Offences Committee of 2014. These reports were followed by legal reforms in 2005, 2013 and 2018. In the following section 3, we will deal specifically with the current rape legislation. To avoid repetitions, as the report of the Sexual Offences Committee of 2014 forms part of the preparatory work for current legislation, this means that we will deal with the latter report in the next section.

Although the focus is on the process referred to above, we provide a slightly broader context and start in the distant past. This is to show how perceptions of interest's worthy of protection by criminalisation have varied over time and to highlight certain problematic features associated with previous rape legislation (use of force): problems that current rape legislation is intended to counteract. Another reason is that present- 
day application of law sometimes reflects notions of body, sexuality, subject and autonomy that can be traced far back in time. In order to understand the legislation of today and shape the legislation of tomorrow, it is important to analyse the law in a broader context.

In connection with this overview, we also emphasise the importance of certain political breakthroughs in gender equality policy which have influenced the general perception of what should constitute rape, which in turn has fostered changes in the legal definition of rape in recent years.

Initially, we also wish to underline that neither the legal shift nor other law reforms concerning sexual offence legislation have been implemented painlessly. Instead they have been the subject of a heated public debate. It is obvious that reforms throughout history that have aimed to strengthen the protection of women against violence, including sexual violence, for example by extending criminal liability for rape or sexual abuse, have been constantly met with criticism and opposition.

\subsection{The distant past - what and who to protect?}

The legal definition of rape, as well as the underlying interests that are protected by law, has varied over time. Until the introduction of the Penal Act in 1864, rape was considered a property crime and not as an attack on the woman - based on a view of the woman as the property of either her father or her husband. After 1864, rape became a crime of freedom. One purpose was to ensure that the woman was protected against violence, but the main reason was to protect the woman's honour. However, the law required the perpetrator to have used heavy and considerable force against the victim, who also was expected to have strongly resisted. ${ }^{14}$

The current Swedish Criminal Code (SCC), which came into force in 1965, introduced rape in the chapter that dealt with Moral Crimes. Rape legislation aimed to ensure protection against sexual abuse and protection of the individual's integrity. ${ }^{15}$ Before the Swedish Criminal Code was introduced, there was a discussion of how much violence that was required to force someone to have sex in order for the act to be considered as rape. The requirement for violence in the crime of robbery at the time was significantly lower - objects and money were thus better protected than a woman's body. ${ }^{16} \mathrm{~A}$ bill to reduce the requirement for the degree of violence for rape to the same level as robbery was at the time met with strong opposition. Another heated debate that created outrage was the proposal to criminalise marital rape. As a result of the introduction of the Swedish Criminal Code in 1965, marital rape was criminalised

14 Leijonhufvud 2015 p. 19, Hassan Jansson, Kvinnofrid: Synen på våldtäkt och konstruktionen av kön i Sverige 1600-1800 (Historiska institutionen, Uppsala universitet 2002) p. 51 ff., 162.

$15 \quad$ Leijonhufvud 2015 p. 19.

$16 \quad$ Ibid. 
and considered to be serious sexual abuse by a man of his wife. ${ }^{17}$

Leijonhufvud states that the intense opposition to criminalise domestic violence and abuse, including rape, should be seen against the background of the classic liberal rule of law model, that also divides life into a public sphere and a private sphere. ${ }^{18}$ According to this notion, the private sphere was considered to be kept safe from state control. Another way of expressing it, is that the individual's, i.e. the man's freedom in the private sphere was unrestricted - while women's freedom not to be subjected to violence and rape was absent from statutory regulation, i.e. was not regarded as important or given priority by the law. The arguments against criminalisation of marital rape were mainly based on religious beliefs where sexuality is closely linked to reproduction. Additionally, notions of gender and differences between the sexes, for example the shortcomings of women and men's irrepressible sexual drives were considered to be obstacles to criminalisation. ${ }^{19}$

These views are also closely linked to Rubin's critique of the essentialist view of sexuality in the Western world, where sex is viewed as something bad until it is legitimised by acceptable causes, such as marriage, love or reproduction. ${ }^{20}$ These ideas derive from a view of a woman as either a wife/mother/Madonna (an honourable woman) or a whore. Eduards, who discusses body politics, stresses that these notions of different kinds of women have in common that female bodies are seen as sexually accessible to men, an object of male fantasies and desires. ${ }^{21}$ This view, where a woman is seen as either an honourable woman or a whore, can be discerned in court cases in modern times. ${ }^{22}$ An example is a case from 2011 that concerned a claim for damages. In the case, the plaintiff claimed compensation of SEK 7,000 for violation of her personal integrity and for pain and suffering, both physical and mental. ${ }^{23}$ The district court concluded that it was undisputed that the defendant (the husband) had given the plaintiff (his wife) a slap on the ear, and he was found guilty of minor assault. However, the court considered that the compensation for the offence should be reduced (to SEK 5,000) as

17 Ibid.

$18 \quad$ Ibid. p. 23.

19 Ibid. p. $20 \mathrm{ff}$.

20 Rubin, Thinking Sex: Notes for a Radical Theory of the Politics of Sexuality in The Lesbian and Gay Studies, eds. Abelove, Barale \& Halperin (Routledge 1993).

21 Eduards, Förbjuden handling - om kvinnors organisering och feministisk teori (Liber 2005) and Westerstrand, Mellan mäns händer. Kvinnors rättssubjektivitet internationell rätt och diskurser om prostitution och trafficking (Uppsala universitet 2008).

22 Research on rape myths confirms that this is still the case. See for example Temkin, Gray \& Barret, Different Functions of Rape Myth Use in Court: Findings From a Trial Observation Study, 13(2) Feminist Criminology (2018) pp. 205-226, Ellison \& Munro, Reacting to Rape. Exploring Mock Jurors' Assessments of Complainant credibility, 49 British Journal of Criminology (2009) pp. 202219 and Adolfsson, Blaming Victims of Rape. Studies on Rape Myths and Beliefs About Rape (Dept of Psychology, University of Gothenburg 2018).

23 Svea hovrätt B 4621-10. 
the wife had caused jealousy by having dinner with another man and arriving home late, and had made herself unavailable on her phone. The verdict was appealed to the Court of Appeal, which instead found the defendant guilty of assault. The act was considered a serious violation of the plaintiff's personal integrity and had taken place in her home, where she could expect to feel safe. The Court of Appeal decided that compensation for the offence should be set at SEK 7,000. In addition, the Court of Appeal ruled that the district court's judgment contained elements of value that were clearly detrimental to the plaintiff as well as information not relevant to the prosecution.

This case concerned an offence of assault (SCC 3:5), but is relevant to this discussion since it involves a husband's assault on his wife due to her 'inappropriate' behaviour. What the district court actually did was to evaluate the woman's behaviour based on underlying norms and notions and then conclude that it is inappropriate behaviour. Instead of assessing the perpetrator's actions as a basis for the claim for damages, the focus was on the victim and her behaviour before and during the assault. We argue that the district court's grounds for its judgement can best be understood if it is set against the notion of a woman as either an honourable woman or a whore. To put it simply, according to this notion her behaviour exceeded the limits of what is expected of an honourable wife..$^{24}$

\subsection{In between - 1984 reform and gender equality policy's impact on rape legisla- tion}

As can be seen from the figure above, in 1984 the sexual offences legislation underwent thorough reform. The heading of Moral Offences was replaced by the heading Concerning Sexual Offences in the Criminal Code. ${ }^{25}$ Rape legislation became gender-neutral, and women and transgender persons could consequently be both rape victims and perpetrators. The legislative changes meant that the prerequisite intercourse remained unchanged and referred to intercourse between a man and a woman, but that the concept of rape was expanded to also include sexual acts that are comparable to intercourse. A special penalty scale was introduced for aggravated rape cases. The prerequisite 'violent' (våldförande) was removed, and the victim's actions before the abuse and her relationship to the perpetrator were considered irrelevant to the criminal classification. The required amount of violence and threats was reduced. The threat did not need to entail 'urgent danger', and threats that appeared dangerous to the threatened person were also included in the rape legislation. The main argument in favour of the changes was that the pre-

24 The discussion on how the lawmakers as well as the courts deal with cases differently based on the situation at hand, from the dichotomy of whore/Madonna, is at present relevant in order to understand/analyse the relationship between the two crimes, rape and the prohibition of purchase of sexual services. For a brief discussion, see section 4 below.

25

Prop. (1983/84:105) New Sexual Offences Legislation. 
vious rape legislation ${ }^{26}$ was partly based on antiquated views about of women. ${ }^{27}$

Contemporary reforms of sexual offences legislation should be seen in the light of the progressive gender equality politics. Most important was the acceptance of the genus system theory presented by Yvonne Hirdman as a part of an official report. ${ }^{28}$ Svensson points out that the most noteworthy about the theory is:

'[...] the understanding of sex equality as a complex issue, related to symbols, structures and individuals. Further, the theory has affected the way sex/gender is conceptualized: as a relationship, instead of a categorisation: the conflict between the sexes has become more visible and sex inequality is now seen as a matter of unequal power. Men benefit from the sex/gender relationship more than women do.'29

This knowledge as the basis for the Swedish Gender Equality Policy was adopted in 1994 through the Government Bill The Gender Equality Policy: Shared Power and Shared Responsibility ${ }^{30}$ and is still applied today. Regarding how the law can be affected in accordance with the theory, Svedberg writes:

'According to the theory, the gender system is maintained by two principles. Firstly, the sexes are kept apart in all areas of life. Secondly, the male is the standard for a human being. At the same time, the male norm permeates every aspect of society, that is, from how the world is understood to which power relations should be regulated legally.31

The unequal power relationship between the sexes is manifested in every area of life, from gender-related violence (especially sexual violence) to unjustified pay differences. These principles have thus influenced legislation and its application, e.g., how rape has historically been defined and the fact that rape within marriage was not criminalised until $1965 .{ }^{32}$

As a part of the Gender Equality Policy the definition of rape was extended at the same time through the Government Bill Women's Peace. The concept of intercourse

26 By 'previous rape legislation' we mean the rape legislation prior to the 1984 reform.

27 Prop. (1983/84:105).

28 SOU (1990:44) Democracy and power in Sweden. Main report of the Inquiry.

29 Svensson, Sex equality: changes in politics, jurisprudence and feminist legal studies in Responsible selves: Women in the Nordic legal culture, eds. Gunnarsson, Nousiainen, Lundström \& NiemiKiesiläinen (Ashgate 2001) p. 72.

30 Prop. (1993/94:147) Gender Equality Policy: Shared Power and Shared Responsibility.

$31 \quad$ Svedberg 2013 p. 486.

32 In other countries, marital rape was criminalised in Canada in 1983, in the UK in the early 1990s (C.R. v. United Kingdom, appl. No 20190/92, 27.6.1994) and in Finland in 1994, see Jokila \& Niemi 2020 p. 128. 
would also be equated with other sexual activity if the act, with regard to the nature of the violation and other circumstances, was comparable to forced intercourse. The purpose of this extension of the definition of rape was to emphasise the nature of the violation instead of the sexual act. ${ }^{33}$ Examples of such acts that involve a violation comparable to those that occur during forced intercourse are to insert an object or a fist into a woman's vagina or anal opening. The bill states that there must be an objective assessment of whether the act typically involves such a serious violation that may occur during forced intercourse. In addition, in some cases, omission to report and expose certain serious sexual offences would be punishable. However, notwithstanding the efforts to improve the protection of the sexual integrity, Leijonhufvud argues that this period was not characterised by a unified view of the need to use criminal law to combat sexual abuse - even when the victims were children. ${ }^{34}$

The Government Bill Women's Peace was adopted in 1998. This reform can be seen as being a result of progressive gender equality policy. ${ }^{35}$ As a result of this bill, the crime of gross violation of a woman's integrity was introduced into the Criminal Code and the Act Prohibiting the Purchase of Sexual Services (1998:408) was adopted. However, the latter act was repealed in 2005, and the crime was implemented in the Criminal Code through Government Bill 2004/05:45. It should be noted that the Prostitution inquiry of 1993 was heavily criticised as it proposed that both parties' acts should be criminalised, i.e. both the seller and the buyer. ${ }^{36}$ This was possible due to the inquiry's choice to use the term 'sex trade'. According to the inquiry, the term 'sex trade' describes an activity in which at least two parties purchase or sell sexual services and which is intended to satisfy the purchaser's sexual drive. This proposal, particularly the idea of criminalising the person exploited by prostitution, was rejected and never implemented in the subsequent Government Bill, Women's Peace. Only the purchase of sexual services was criminalised. The proposal was criticised on the basis that it was founded on a notion of two equal contractual partners. This view of prostitution was heavily rejected, and instead it was stated that prostitution is an unequal power relationship where the woman is the one who is exploited. The '[...] legislative proposal stated that it is shameful and unacceptable that, in a genderequal society, men obtain casual sexual relations with women in return for payment and that Sweden, by introducing a ban on purchasing sexual services, also sent an important signal to other countries highlighting our outlook on purchasing sexual services and prostitution. ${ }^{37}$ In addition, it was pointed out that prostitution entails serious harm to both individuals and to society. 'It was expected that criminalisation would have a deterrent effect on prospective purchasers of sex and serve to reduce

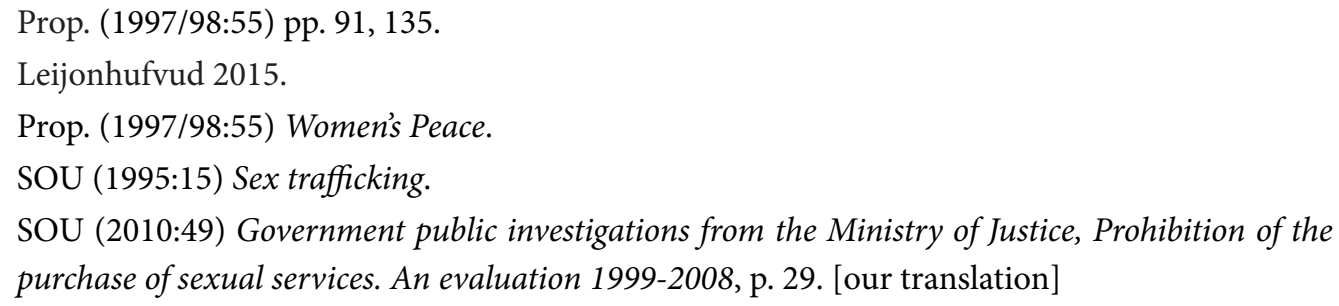


the interest of various groups or individuals abroad in establishing more extensive organised prostitution activities in Sweden, which would have an inhibitory effect on the prevalence of prostitution here [our translation]..$^{38}$ The reason why this law is described and commented on here is that the requirement for voluntariness in the current rape legislation is considered problematic when it comes to drawing the line between the two crimes of rape and purchase of sexual services, and thus autonomy.

\subsection{Consent is entering the political and legal discussion}

It should be emphasised that 1998 was the first time the concept of lack of consent as the basic requirement for criminal liability was investigated in Sweden. Ten years later, the issue was brought up again. ${ }^{39}$ Sixteen years after the first inquiry was initiated terms of reference for a new inquiry were adopted, albeit with a slightly different wording. The committee were to 'consider whether a consent-based regulatory model for rape should be introduced'. ${ }^{40}$ The change in wording might have represented a breakthrough, because it opened the possibility for introducing 'another' basic requirement for criminal liability, i.e. voluntariness. As a result, the committee was able to circumvent the key arguments against the introduction of a lack-of-consent construction presented in the previous inquiries. The inquiry led to a proposal of voluntariness as a decisive criterion for criminal liability subsequently adopted in the Government Bill New Sexual Offence Legislation Based on Voluntariness, ${ }^{41}$ which entered into force in July 2018. For clarity, we will discuss the reports in a chronological order and begin with the 1998 inquiry below.

\subsubsection{Sexual Offences Committee of 1998}

The Sexual Offences Committee of 1998 examined, among other things, whether the requirement of violence or coercion for certain sexual offences should be removed and instead be replaced by lack of consent..$^{42}$ The inquiry followed after a series of media reports of gang rapes which occurred in the summer of 1997 (referred to as the Södertälje case and the Rissne case) which led to a widespread criticism of the legislation at the time. ${ }^{43}$ The problem in these cases was that the '[...] victim had not passed out (which would have qualified as sexual abuse), nor was there evidence to show use of force or resistance by the victim (which would have qualified as rape). ${ }^{44}$

\footnotetext{
38 SOU (2010:49) p. 29. [our translation]

39 SOU (2008: 94) Evaluation of the 2005 sexual offence reform, etc.

$40 \quad$ SOU (2014:123) Review of the rape legislation, p. 1.

41 Prop. (2017/18: 177) A new sexual offence legislation based on voluntariness.

42 SOU (1998:48) Review of sexual offence legislation.

43 Sutorious, Den rättsliga prövningen av våldtäkt och kvinnors sexuella självbestämmanderätt reflektioner med anledning av en rättsfallskommentar in Juridisk Tidskrift (1997/98) pp. 1297, Jokila and Niemi 2020.

$44 \quad$ Jokila and Niemi 2020 p. 123.
} 
To begin with, it should also be noted that the Committee on Sexual Offences of 1998 did not interpret the terms of reference for the inquiry as a paradigm shift but instead interpreted it linearly. They placed violence and coercion at one end of this line and lack of consent at the other. When the inquiry then discussed arguments for each of these alternatives, they slipped along this line. The Sexual Offences Committee's interpretations of lack of consent can be understood as follows: ' ...] the woman must have been so clear and persistent in her rejection of intercourse that the perpetrator deliberately puts himself above her lack of consent to intercourse [our translation and remark].45 Thereby, the Committee interpreted the terms of reference as if the legislation was based on lack of consent, the woman does not have to protest as much as she has to due to a legislation based on use of force, but it is still her primary task to protest. The protests do not have to be as clear as with a use of force construction, but they must be so clear that the lack of consent is clear to the perpetrator. Hence, the Sexual Offences Committee 1998 at the time did not interpret the terms of reference as a paradigm shift: that the person who has intercourse has an active responsibility to ensure that the other has consented. 'The paradigm shift would mean that the woman's primary task of protesting becomes the man's primary task of asking. ${ }^{46}$

The Sexual Offences Committee 1998 balanced arguments for and against a lack of consent construction and considered that the use of force construction should remain. Instead, the inquiry proposed that criminal liability for rape should be extended to include abuse of a situation of helplessness. The inquiry feared retrogression of gender equality and referred to the Government's efforts and measures taken in other areas of life to attain gender equality in society, and in particular to the Government Bill Women's Peace. ${ }^{47}$ The inquiry was concerned that there would be irrelevant focus on the victim (the woman) in the legal process, such as the woman's actions before, during and after the assault, for example that her clothes would be deemed significant with regard to whether consent had been given. Regarding the argument about difficulty in defining consent, the inquiry referred to the general grounds for freedom from criminal liability due to consent in SCC 24:7. The use and interpretation of consent in rape legislation should be compatible with the general provision. The inquiry also rejected the idea that it should be the perpetrator's responsibility to make sure that he has consent to sexual intercourse. It was considered difficult to draft such a provision and it was also stated that such a provision would be in conflict with the principle that it is the prosecutor who bears the burden of proof in criminal cases. ${ }^{48}$ We will shortly see that this unthinkable construction was not so unreasonable.

\footnotetext{
$45 \quad$ Svedberg 2005 p. 90.

$46 \quad$ Ibid. [our translation]

47 Prop. (1997/98:55).

$48 \quad$ Ibid.
} 
The 1998 inquiry was followed by the Government Bill New Sexual Offences Legislation. ${ }^{49}$ As a result of the Bill, sexual offence legislation underwent a comprehensive reform in 2005. Among other changes, the crime of rape was extended further. The requisite 'sexual intercourse' was replaced by 'sexual act'. It was argued that 'sexual intercourse' implied reciprocity and not abuse. Furthermore, the definition of rape was extended to include the situation in which a person commits a sexual act by exploiting the other person's inability to defend herself due to intoxication or a similar condition or a threatening situation. The rape laws at the time required the perpetrator to have caused the helplessness or a similar state of incapacitation, thus this did not include the situations in the Södertälje and Rissne cases, where the victim was gang-raped due to self-intoxication.

\subsubsection{Sexual Offences Committee of 2008}

The second inquiry on the question of lack of consent or use of force was made by the Sexual Offences Committee of $2008 .^{50}$ The committee submitted its final report in 2010, forming the basis for the reforms of $2013 .{ }^{51}$ The inquiry referred to the Sexual Offences Committee of 1998. Like the previous study, the inquiry weighed up the pros and cons of imposing legislation based on the lack of consent. The benefits of a lack-of-consent construction were considered on the one hand to be a natural continuation of the development of sexual offences and its normative effects, such as a shift in focus towards the actions of the defendant and better treatment of the victim in the legal system, especially with regard to the police. On the other hand, the change was considered to increase the focus on the victim and cause difficulties in defining consent and in distinguishing between valid and invalid consents. In addition, it could result in uncertainty of the extent of the criminalisation, unreasonable expectations of more convictions and an increased risk of sexual moralism. According to the committee, the meaning of consent should be stated directly in the legislation. The inquiry considered that pure consent-based legislation, i.e. lack of consent as the basic and only criminal element, should not be introduced. The government '[...] once again made the assessment that the disadvantages that legislation based on consent would entail were not outweighed by the advantages ${ }^{52}$ presented by the Sexual Offences Committee of 2008. The inquiry proposed that the legislation should be supplemented by a subordinated crime under the heading of sexual abuse when the requirements for rape (i.e. violence, threats or helplessness) was not fulfilled but the sexual act had been carried out 'without permission'. Leijonhufvud stresses that

Prop. (2004/05:45).

SOU (2008:94).

Prop. (2012/2013:111).

Nilsson, Towards voluntariness in Swedish rape laws Hyper-medialised group rape cases and the shift in the legal discourse in Rape in the Nordic Countries: Continuity and Change, eds. Heinskou, Skilbrei \& Stefansen (Routledge 2020) p. 114. 
the purpose behind the inquiry's 'solution' of maintaining the structure at the time but instead introducing a subordinated crime, was to be less provocative ${ }^{53}$ However, the proposal was never implemented. Instead the wording 'helplessness' was replaced by 'particularly vulnerable situation. Several examples of such 'particularly vulnerable situations' were included in the new legislation, such as unconsciousness, illness, bodily injury or mental disturbance and with the addition 'or otherwise in consideration of the circumstances. The change was based on a number of court cases where the criterion 'helpless situation' was discussed, where the victim was not considered for example to be sufficiently drunk to be in a 'helpless situation. ${ }^{54}$

As a way to critically analyse the inquiry, we want to pay attention to '[...] the way in which they take as given the 'material' for analysis', a method inspired by Bacchi. ${ }^{55}$ She emphasises that how a problem is presented and how the framework is set for the problem can make some societal solutions possible and others impossible. According to Bacchi's method 'What's The Problem' one should begin with questions such as 'what is the problem?'; 'what presuppositions are implied or taken for granted?' and 'what effects are connected to these representations?' ${ }^{56}$ We argue that methodological studies of representations of problems are important to see connections and make visible how certain issues are excluded from the political agenda. This approach require of us '[...] to reflect upon which issues remain unaddressed or undiscussed because of the ways certain 'problems' are represented. ${ }^{57}$ It is hence obvious that the dominant problems represented in the inquiry point at not imposing a requirement of lack of consent. We therefore wish to draw attention to the fact that the inquiry takes the previous inquiry for granted and as a basis for its position. ${ }^{58}$ Other solutions could have emerged if the inquiry had framed the 'problems' differently and beyond single issues. One should begin by asking 'what is the problem?'

\section{Hypothetical use of What Is The Problem 1}

When the inquiries investigated the prerequisites for a change from use of force to lack of consent, they started by asking what is the problem with a change in current rape legislation? (This is hypothetically formulated)

Their answer, i.e. the problem represented, is that the victim would be at the centre of the legal process and that the meaning of consent is hard to define.

Hence, the solution must be to maintain the requisite use of force.

Leijonhufvud 2015.

SOU (2008:94).

Bacchi, Women, policy and politics: the construction of policy problems (Sage 1999) p. 2.

Bacchi 1999.

Bacchi 1999 p. 2.

See above, Svedberg's critique of the Sexual Offences Committee of 1998 interpretation of the inquiry terms of reference. 
This line of argument is logical and therefore easy to find convincing. What we suggest, when using Bacchi's method, is that the problem could have been formulated differently, and then other solutions could have followed the inquiries.

\section{Hypothetical use of What Is The Problem 2}

When the inquiries investigated the prerequisites for a change from use of force to lack of consent, they started by asking: what is the problem with the current rape legislation? (This is hypothetically formulated)

Their answer, i.e. the problem represented, could then have been that current rape legislation presupposes that the female body is available until she protests. This, in turn, means that she is made responsible for the criminal act not taking place. ${ }^{59}$

Hence, the solution would then have been for responsibility for the criminal act being placed on the perpetrator, by changing the requisite use of force to (lack of) consent, i.e. the perpetrator should make sure that the sexual act is mutual.

In this context Wegerstad's analysis of how problems related to sexual offences are represented and affect legal reforms could serve as an example of feminist legal research related to this method. She describes the historical reforms concerning how to define the rape act as a shift from bodily harm to violation of personal and sexual integrity ${ }^{60}$ However, she also emphasised that the Women's Peace inquiry, ${ }^{61}$ compared to previous reforms, had an opposite perspective of sexual abuses. The inquiry's problem formulation is instead based on women's experiences and sexualised violence, where the prerequisite 'sexualised violence' is based on a description of a societal problem on a structural level. Wegerstad's conclusion is that the first half of the 2000s was focusing on the harmful act and that this was based on the acting subject's bodily expression of sexual drive, but then changed into what the act does to the victim, i.e. violation of integrity. Further, she concludes that sexual offences in general are created through two different problem formulations. On the one hand, sexual crime is constructed as a matter of gender-based violence, where sexual crime is a gender equality problem that is described as men's violence against women. On the other hand, sexual crimes are constructed as a matter of sexuality, in which sexual crimes are instead a universal and individual problem. According to Wegerstad, it is the latter (problem) formulation that has an impact on the reform in 2005, and also on the reform in $2013 .{ }^{62}$

\footnotetext{
59 See the opening quote of the article.

$60 \quad$ Wegerstad 2015 p. 166.

${ }_{61}$ SOU (1995:60) Women's Peace. Note that the inquiry report and the Government Bill have the same title.

$62 \quad$ Wegerstad 2015 p. 186.
} 


\section{The current rape legislation - general reflections}

\subsection{Introduction}

In this section we describe and discuss the new criminal legislation on rape that entered into force on the 1 July 2018, characterised by voluntariness instead of use of force being the central criterion. This section have five parts following the general introduction. The first is a more in-depth introduction to the new legal construction of rape (3.2). The second highlights important aspects from the discussions in the legislative process stemming from the Sexual Offences Committee of 2014 (3.3). In the third part we address some specific aspects of the legal construction concerning some linguistic and normative shifts (3.4). In the fourth part we discuss some issues related to the application of the new legislation (3.5), and in the last part we introduce a discussion on autonomy (3.6). We start out in the previous and new legislation as a backdrop for the coming discussions, see figure below.

Figure 2.

\begin{tabular}{|c|c|c|}
\hline Rape SCC 6:1 (before the 1st of July 2018) & Rape SCC 6:1 (after the 1 st of July 2018) & Negligent rape SCC 6:1 a (after the 1st of July 2018) \\
\hline $\begin{array}{l}\text { A person who, by violence or use of force or by threat which } \\
\text { involves an offence, forces another person to have sexual } \\
\text { intercourse or to engage in another sexual act that in the view of } \\
\text { the seriousness of the violation is comparable to enforced sexual } \\
\text { intercourse, shall be sentenced for rape to imprisonment for at } \\
\text { least two and at most six years. } \\
\text { The same shall apply to a person who carries out sexual intercourse } \\
\text { or a sexual act, that in accordance with paragraph one is } \\
\text { comparable to sexual intercourse, by improperly exploiting that a } \\
\text { person is in a particularly vulnerable situation due to } \\
\text { unconsciousness, sleep, grave fear, the influence of alcohol or } \\
\text { drugs, illness, bodily injury, mental disturbance or otherwise in view } \\
\text { of the circumstances. } \\
\text { If an offence referred to in the first or second paragraph, in view of } \\
\text { the circumstances associated with the offence, is considered less } \\
\text { serious, the person is guilty of rape and is sentenced to } \\
\text { imprisonment for at most four years. } \\
\text { If an offence referred to in the first or second paragraph is } \\
\text { considered gross, the person is guilty of gross rape and is sentenced } \\
\text { to imprisonment for at least four and at most ten years. When } \\
\text { assessing whether the offence is gross, particular consideration is } \\
\text { given to whether the perpetrator used violence or a threat of a } \\
\text { particularly serious nature, or whether more than one person } \\
\text { assaulted the victim or tool part in the assault in some other way or } \\
\text { whether, in view of the method used or otherwise, the perpetrator } \\
\text { exhibited particular ruthlessness or brutality. (2013:365) }\end{array}$ & $\begin{array}{l}\text { A person who performs sexual intercourse, or some other sexual } \\
\text { act that in the view of the seriousness of the violation is } \\
\text { comparable to sexual intercourse, with a person who is not } \\
\text { participating voluntarily is guilty of rape and is sentenced to } \\
\text { imprisonment for at least two and at most six years. When } \\
\text { assessing whether participation is voluntary or not, particular } \\
\text { consideration is given to whether voluntariness was expressed by } \\
\text { word or deed or in some other way. A person can never be } \\
\text { considered to be participating voluntarily if: } \\
\text { Their participation is a result of assault, other violence or } \\
\text { threat of a criminal act, a threat to bring a prosecution against } \\
\text { or report another person for an offence, or a threat to give } \\
\text { detrimental information about another person; } \\
\text { The perpetrator improperly exploits the fact that the person } \\
\text { is in a particularly vulnerable situation due to } \\
\text { unconsciousness, sleep, grave fear, the influence of alcohol or } \\
\text { drugs, illness, bodily injury, mental disturbance or otherwise in } \\
\text { view of the circumstances; or } \\
\text { The perpetrator induces the person to participate by seriously } \\
\text { abusing the person's position of dependence on the } \\
\text { perpetrator. } \\
\text { If, in view of the circumstances associated with the offence, } \\
\text { the offence is considered less serious, the person is guilty of } \\
\text { rape and is sentenced to imprisonment for at most four years. } \\
\text { If an offence referred to in the first paragraph is considered } \\
\text { gross, the person is guilty of gross rape and is sentenced to } \\
\text { imprisonment for at least five and at most ten years. When } \\
\text { assessing whether the offence is gross, particular } \\
\text { consideration is given to whether the perpetrator used } \\
\text { violence or a threat of a particularly serious nature, or } \\
\text { whether more than one person assaulted the victim or took } \\
\text { part in the assault in some other way, or whether, in view of } \\
\text { the method used or the young age of the victim or otherwise, } \\
\text { the perpetrator exhibited particular ruthlessness or brutality. } \\
\text { (Act } 2018: 618 \text { ) }\end{array}$ & $\begin{array}{l}\text { A person who commits an act referred to in Section } 1 \\
\text { and is grossly negligent regarding the circumstance } \\
\text { that the other person is not participating voluntarily is } \\
\text { guilty of negligent rape and is sentenced to } \\
\text { imprisonment for at most four years. } \\
\text { It, in the view of the circumstances, the act is less } \\
\text { serious, the person is not held responsible. Act } \\
\text { 2018:618. person who commits an act referred to in } \\
\text { Section } 1 \text { and is grossly negligent regarding the } \\
\text { circumstance that the other person is not participating } \\
\text { voluntarily is guilty of negligent rape and is sentenced } \\
\text { to imprisonment for at most four years. } \\
\text { It, in the view of the circumstances, the act is less } \\
\text { serious, the person is not held responsible. Act } \\
2018: 618 .\end{array}$ \\
\hline
\end{tabular}


The new regulation of the offence, in SCC 6:1, is defined as: ${ }^{: 3}$

'A person who performs sexual intercourse, or some other sexual act that in the view of the seriousness of the violation is comparable to sexual intercourse, with a person who is not participating voluntarily is guilty of rape and is sentenced to imprisonment for at least two and at most six years. When assessing whether participation is voluntary or not, particular consideration is given to whether voluntariness was expressed by word or deed or in some other way. A person can never be considered to be participating voluntarily if: 1. Their participation is a result of assault, other violence or threat of a criminal act, a threat to bring a prosecution against or report another person for an offence, or a threat to give detrimental information about another person;

2. The perpetrator improperly exploits the fact that the person is in a particularly vulnerable situation due to unconsciousness, sleep, grave fear, the influence of alcohol or drugs, illness, bodily injury, mental disturbance or otherwise in view of the circumstances; or

3. The perpetrator induces the person to participate by seriously abusing the person's position of dependence on the perpetrator.

If, in view of the circumstances associated with the offence, the offence is considered less serious, the person is guilty of rape and is sentenced to imprisonment for at most four years.

If an offence referred to in the first paragraph is considered gross, the person is guilty of gross rape and is sentenced to imprisonment for at least five and at most ten years. When assessing whether the offence is gross, particular consideration is given to whether the perpetrator used violence or a threat of a particularly serious nature, or whether more than one person assaulted the victim or took part in the assault in some other way, or whether, in view of the method used or the young age of the victim or otherwise, the perpetrator exhibited particular ruthlessness or brutality. (Act 2018:618)'

\subsection{Introduction to the legal regulation of rape}

\subsubsection{The decisive criterion - not participating voluntarily}

The new legal construction of rape means that the boundary between a legal and illegal act is now decided by whether the participation in a sexual act is voluntary or not, i.e., the legal construction requires that someone performs 'sexual intercourse or similar ${ }^{64}$ with a person who does not participate voluntary. This includes two situations: 1) a person has not by free will decided to participate in 'sexual intercourse or similar', meaning that someone has not by word or deed expressed a 'yes'; or 2) a person has by free will decided not to participate in 'sexual intercourse or similar',

63 The translations of the current legislation is found at $<$ https://www.regeringen.se/rattsligadokument/departementsserien-och-promemorior/1999/01/ds-199936/>. [the authors italics and underlining]

${ }^{64}$ The definition of the sexual act was neither discussed nor changed in this most recent reform, and will therefore not be dealt with in this part. These discussions have been analysed in previous legislative processes and in the previous section. 'Sexual intercourse or similar' is simplified and refers to the required element in the regulation of rape. 
meaning a person has expressed a 'no'.65 The assessment of the voluntariness should be based on the situation as a whole. ${ }^{66}$ This construction has been criticised on the grounds that the boundary between voluntary and non-voluntary participation is unclear and cannot be ascertained until afterwards. ${ }^{67}$ Additionally, the inner will of a person not to participate in a sexual act if the person has in fact agreed to it, is not enough as grounds for criminal responsibility. ${ }^{68}$ This has been interpreted as a situation where someone has expressed voluntariness in some way even though she did not really want to participate. The determining factor is whether she was able make a free decision or not. The Government held that this is a way to use one's sexual self-determination, to choose to do something one would rather avoid. ${ }^{69}$ This is an interesting view of self-determination and closely linked to the idea of autonomy, and will be discussed more in section 4 . The participation must be voluntary when the sexual act is carried out and the whole time. ${ }^{70}$

\subsubsection{A particular criterion to clarify how to assess voluntariness}

The second sentence states that in the assessment of whether the participation has been voluntary or not, expression of voluntariness by words or deed shall be taken into special account. Examples of such deeds given in the preparatory work are facial expressions or body language. ${ }^{71}$ This means that a crucial part of the legal assessment must include the question of what the victim has or has not expressed. Note that there is no requirement that such an expression must have taken place under the participation to be voluntary, which means that being passive can also constitute voluntary participation. The Sexual Offences Committee of 2014 suggested that the offence of rape should contain a requirement for expression of the voluntariness, which would mean that tacit consent would be void. The committee held that allowing for tacit consent to be sufficient would risk increasing prejudice about passivity in sexual relations and would make it impossible to distinguish frozen fright, illness or drunkenness from passive consent, ending up in a situation where only a 'no' is

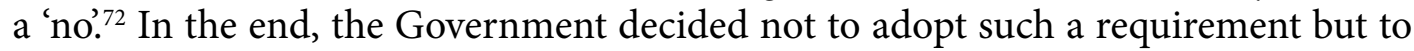
adopt a modified version. The purpose of the second sentence is to underline that the point of departure must be that voluntariness to participate in a sexual activity will be expressed in some way and that the absence of such expressions normally should

65 Wennberg, Befogad kritik av det nya våldtäktsbrottet? in Juridisk tidskrift (2018/19) pp. 298-304, p. 300.

66 Prop. (2017/18:177) p. 78.

67 Council on Legislation statement (23.01.2018) p. $4 \mathrm{f}$.

68 Prop. (2017/18:177) s. 78.

${ }_{69} \quad$ Prop. (2017/18:177) p. 33, see also Gustafsson Yakoub, Två sätt att tolka det nya våldtäktsbrottet in Svensk juristtidning (2020) p. 110.

$70 \quad$ Prop. (2017/18:177) p. $78 \mathrm{f}$.

71 Prop. (2017/18:177) p. 80.

$72 \operatorname{SOU}(2016: 60)$. 
be interpreted as non-voluntariness. Tacit consent might, in exceptional cases, be enough to not constitute rape. ${ }^{73}$

\subsubsection{Three situations when voluntariness is void}

It should be noted that voluntariness, irrespective of whether and how it has been expressed, is not valid in three specific situations mentioned in the third sentence of SCC 6:1: A person can never be considered to be participating voluntary if: 1 . Their participation is a result of assault, other violence or threat of a criminal act, a threat to bring a prosecution against or report another person for an offence, or a threat to give detrimental information about another person (use of force); or 2. The perpetrator improperly exploits the fact that the person is in a particularly vulnerable situation due to unconsciousness, sleep, grave fear, the influence of alcohol or drugs, illness, bodily injury, mental disturbance or otherwise in view of the circumstances (particular vulnerable situation) or; 3. The perpetrator induces the person to participate by seriously abusing the person's position of dependence on the perpetrator (a serious abuse of a person's position of dependence). Even if a person has agreed to sex, it does not necessarily mean that the participation is voluntary. The situations mentioned above aims at situations where a person is not capable of protecting, or at least has limited options to protect, her sexual integrity and express her own will. ${ }^{74}$ Wennberg stresses that this part of the regulatory framework is not relevant in situations where a person said 'no' or did not make up her mind in such a way that the participation was not voluntary. ${ }^{75}$ In the draft version of the offence, the third sentence had a slightly different beginning: 'an expressed choice to participate in sexual intercourse is not voluntary if [...]'. This was meant to strengthen the legal protection of sexual integrity, but the committee found it contradictory to include sleep and unconsciousness under paragraph 2 if related to an expressed will, and decided to omit these situations. ${ }^{76}$ The committee also argued that not all situations of sleep should constitute rape. Cases of close relationships where sexual acts could be initiated when one of the parties was asleep should not necessarily fall within the scope of the offence. The discussions led to the removal of the initial formulation of an expressed choice, being replaced by a sentence stating that a person can never participate voluntarily if the circumstances in paragraphs 1-3 are applicable. In the Government Bill, it is argued that some sexual acts carried out in a close relationship when someone is asleep do not constitute improper exploitation and would hence not fall within the scope of the offence of rape. ${ }^{77}$ Wennberg finds this illogical and holds that these situations should fall under the first sentence of the offence, i.e. she is not participating voluntarily. In this sense Wennberg agrees with the critique that the construction of the offence is unclear, but underlines that this

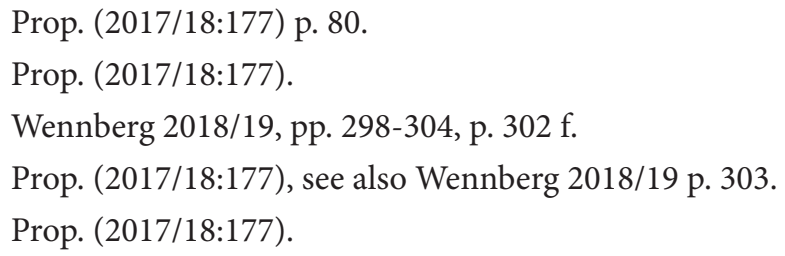


particular situation is peripheral. ${ }^{78}$

Additionally, we wish to address another illogical aspect regarding these three situations where voluntariness is void. If this means that a participation can never be voluntary and hence must constitute rape, we ask the law - what about prostitution? How does these three exceptions relate to the prohibition of purchase of sexual services? It seems as the financial payment overrides the lack of voluntariness as described in paragraphs $1-3 .^{79}$

\subsection{Some aspects from the discussions in the preparatory works}

This section highlights some of the main arguments and discussions from the preparatory works for today's rape legislation. It is a continuation of the previous reviews of inquiries, and hence the third inquiry we discuss in this article. The purpose of the reform was 'to clarify that every person has an unconditional right to personal and sexual integrity and sexual self-determination. ${ }^{80}$ This clarification was made through the change in the decisive criterion from use of force to voluntariness.

The referral bodies raised questions of a varied nature: some of them asked how to define a sexual act, and whether voluntariness must be re-expressed between sexual acts when one sexual act leads on to another; one pointed to a risk of extended criminal legal responsibility in practice, especially if combined with a responsibility for negligence. Another pointed to that in cases of passivity, the most serious situations of lack of voluntariness will fall under the regulation of negligent rape. Other referral bodies expressed concerns about situations where someone initially participates voluntarily, enters a state of frozen fright and becomes unable to express that he or she no longer wishes to participate voluntarily. ${ }^{81}$

The Swedish Government emphasised that the word 'participation' includes both activity and passivity, but argued that a requirement for voluntariness to be communicated in some way would ensure that pure passivity would never be interpreted as a voluntary participation. This would also make the point of departure clearer for the law enforcement authorities. But the Government went on to state that such a requirement could lead to a situation where a person in some way expresses voluntariness although she does not wish to participate and the perpetrator suspects

\footnotetext{
78 Wennberg $2018 / 19$ p. 304.

79 It can be noted that the offence of rape may be applicable in cases of trafficking, but also in other cases, especially when the buyer has used a large amount of force. We will return to this discussion briefly in the next section.

80 Prop. (2017/18:177) p. 1.

81 Prop. (2017/18:177) p. $29 \mathrm{f}$.
} 
this is the case. ${ }^{82}$ The Government argued that the right to sexual self-determination includes both a right to decide whether to participate in sexual practices or not and also to respond to sexual approaches in any way one wishes, including by passivity. The Government held that this means that the legal construction should not include any requirement regarding how persons are to express their voluntary participation in sexual practices and left this issue to the judiciary to decide in each case. ${ }^{83}$

On the one hand, the Government emphasised that it is the responsibility of the perpetrator to ensure that the sexual act is mutual. On the other hand, it emphasised that in the assessment of whether participation is voluntary or not (in the eyes of the perpetrator) the inner will of the victim is irrelevant, what matters is what the victim has communicated. This means that what the victim expressed or did not express is crucial in the assessment of the perpetrator's criminal responsibility. The Government stressed that if a person chose to participate in sexual activities against her will, and the perpetrator did not use force or exploited the victim's vulnerable situation, the act is legal. The Government argued that a result of this is that a situation where someone successfully pesters about sex falls outside the scope of rape. ${ }^{84}$ The Government also argued that a situation when the victim initially participated voluntarily and then entered a state of frozen fright cannot fall under the rape legislation. ${ }^{85}$ The line of arguments addresses and recognises the complexity of autonomy, which we will return to briefly below.

\subsection{The legal construction - linguistic and normative shifts}

In this section we will make some general comments on the new regulatory framework due to previous discussions and criticism that has been in focus. The shift in discourse the last a decade and a half, from use of force towards voluntariness, is now established in Swedish law. The change implies a transfer of responsibility for the criminal act from the victim to the perpetrator. ${ }^{86}$ The change also has an important normative symbolic value as it establishes that (female) bodies are unavailable until the moment the woman says 'yes', whereas previous legislation tended to assume that female bodies were available until the woman said 'no'. This could also be described as an end of an era (hopefully) in the context of rape legislation, with what Eduards describes as the female common feature of being sexually accessible to men. ${ }^{87}$

Regarding the change of wording, from the more established lack of consent to

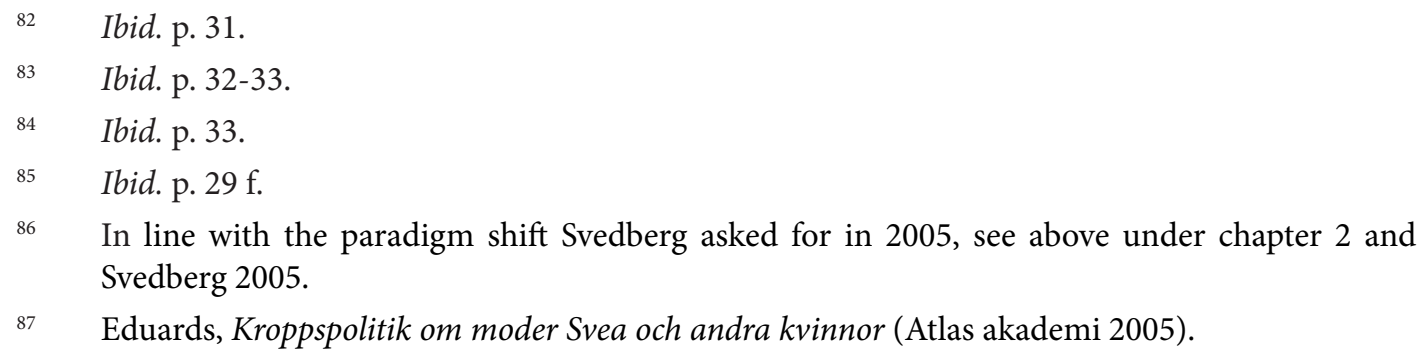


voluntariness, the main reason for this change was the risk of confusion in relation to the general ground for freedom from criminal liability due to consent in SCC 24:7. ${ }^{88}$ The motivation seems reasonable in a Swedish legal context, but we would like to make some comments on the importance of choice of words by addressing the recent discussion in Denmark. As Vestergaard analyses in depth in his article, ${ }^{89}$ the Penal Code Committee has been debating the choice of the two concepts, consent or voluntariness, as the decisive criterion in the new construction of rape in Danish law. Noteworthy here is that Denmark does not have a rule of consent as a general ground for freedom from responsibility. ${ }^{90}$ The majority of the Danish committee suggested a legal construction based on voluntariness, with the wording 'every individual has the right to sexual self-determination and [that] every sexual act must be based on "mutual", whereas, they argued that the concept of consent refers to an agreement situation that seems to require some formal stages. ${ }^{91}$ As an effect, the majority held that this would risk overly extensive criminalisation. The minority of the committee, on the other hand, argued that voluntariness points 'in the direction of one's fulfilment of the other's desire..$^{2}$ This argument is in line with feminist critique of ideas of passive female sexuality and active male sexuality. We agree on this latter linguistic approach with regard to the Danish legislative debate. ${ }^{93}$ Similar discussions can be traced in the legislative work regarding the change from 'sexual intercourse' to 'sexual act' in Swedish rape laws in 2005. ${ }^{94}$

88 The provision in SCC 24:7 set up several criteria that must be fulfilled. The provision on consent as a ground for freedom from responsibility would, for example, exclude situations when consent has been given without full insight into the relevant circumstances, and could hence lead to criminal responsibility. If the legal construction of rape was built on the same concept, situations where the perpetrator has been lying about use of contraceptives or sexually transmitted infections or had falsely promised to engage in a love affair could be defined as rape, see prop. (2017/18:177) p. $30 \mathrm{f}$.

89 Vestergaard, The rape law revision in Denmark: Consent or voluntariness as the key criterion?, 9(2) Bergen Journal of Criminal Law and Criminal Justice (2020) pp. 5-32.

$90 \quad$ Ibid.

91 Ibid.

$92 \quad$ Ibid.

93 The Danish legislative process led to revised rape legislation in September 2020, based on consent, as the minority suggested. The consent must be given voluntarily as an expression of the person's free will. More on the Danish legislative debate in Vestergaard's article, see Vestergaard 2020.

$94 \quad$ Prop. $(2004 / 05)$ p. 45. 


\subsection{Before the court}

Cases of rape are often to a large extent based on supportive evidence and the parties' testimonies. One effect is that the question of credibility is placed at the core of the trial. ${ }^{95}$ One crucial concern in relation to the new offence of rape is the risk of an expanded focus on the victim and her behaviour, due to the requirement that establishes that 'when assessing whether participation is voluntary or not, particular consideration is given to whether voluntariness was expressed in word or deed or in some other way. ${ }^{96}$ The Government, on the other hand rejected such concerns, and argued that the new regulatory framework rather focus on the perpetrator, and refered to Scotland and Canada. ${ }^{97}$

The expressed concerns are closely linked to rape myths. Rape myths have been defined as 'prejudicial, stereotyped, or false beliefs about rape, rape victims, and rapists, ${ }^{98}$ expanded a decade later to include 'attitudes and beliefs that are generally false but are widely and persistently held, and that serve to deny and justify male sexual aggression against women.99 A recent definition underlines both the content and function of these myths in the judiciary: 'descriptive or prescriptive beliefs about sexual aggression (i.e. about its scope, causes, context and consequences) that serve to deny, downplay or justify sexually aggressive behaviour that men commit against women.' ${ }^{100}$

Feminist legal research has dealt with the reproduction of gendered stereotypes in cases concerning rape and the role of rape myths in the application of rape legislation. ${ }^{101}$ One of the strongest rape myths is the one about 'real rape'. A 'real rape' is committed through

95 Andersson 2004; Finch \& Munro, Juror Stereotypes and Blame Attribution in Rape Cases Involving Intoxicants, 45(1) The British Journal of Criminology (2005) pp. 25-38, Saunders, Rape as 'one person's word against another's': Challenging the conventional wisdom, in the International Journal of Evidence and Proof (2018) <https://doi.org/10.1177/1365712718766478>. A recent report from the Swedish National Council for Crime Prevention (BRA) also concludes that the lack of evidence is even more pronounced in cases of negligent rape, see BRÅ report (2020).

96 SCC 6:1.

97 Prop. (2017/18:177) p. 22.

98 Burt, Cultural myths and supports for rape, 38(2) Journal of Personality and Social Psychology (1980) pp. 217-230.

$99 \quad$ Lonsway \& Fitzgerald, Rape Myths. In review, 18(2) Psychology of Women Quarterly (1994) pp. 133-164, p. 134.

100 Gerger, Kley, Bohner, \& Siebler, The Acceptance of Modern Myths about Sexual Aggression (AMMSA) scale: Development and validation in German and English, 33(5) Aggressive Behaviour (2007) pp. 422-440, p. 423.

101 MacKinnon 2016, Bitsch, The Geography of Rape: Shaming Narratives in Norwegian Rape Cases, 44(4) Signs: Journal of Women in Culture and Society (2019) pp. 931-953, Burman 2009, Temkin et al. 2018, Smith and Skinner, How Rape Myths Are Used and Challenged in Rape and Sexual Assault Trials, 26(4) Social \& Legal Studies (2017) pp. 441-466. 
assault, carried out outside, in a public place, between strangers. ${ }^{102}$ A majority of the court cases concern other types of rapes. ${ }^{103}$ In relation to this we wish to link the discussion on rape myths to critique of the low rate of convictions compared to other types of crimes that has been presented in public debate. This problem might be a question of application, rather than the legal construction of the crime, but these two are interrelated and must be seen as a whole. Therefore, it is relevant to note that a report from the Swedish National Council for Crime Prevention (BRA)), in which almost 400 judgments were reviewed, shows that the number of convictions in rape cases has increased considerably from 155 in 2017 to 297 in 2019. ${ }^{104}$ This means that rates of convictions are almost twice as high when the courts are applying the new construction of rape, i.e. built on voluntariness, compared to the old one that was based on use of force. It is too early to draw any firm conclusions at this point, but it might be an indication of a legal construction that is more effective. The result could also imply that the room for rape myths might be demarcated - the construction is mirroring the lived reality, i.e. is more in line with the victim's experiences.

\subsection{Ideas of autonomy - some notes on the requisite of voluntariness}

Criminal law is founded on an idea of the liberal subject. The new Swedish rape legislation is constructed in line with this presupposition about the individual. By using voluntariness as the decisive criterion, the offence clearly builds on the view of two equal parties, in line with the liberal view of the individual, free to make their own choices. ${ }^{105}$ In opposition to this presupposition, the legislation also addresses three situations where unequal powers are recognised, being of such a serious character that the power imbalances must be taken into account. Expressions of voluntariness in these situations are void. These situations are serious violations of the victim's right to self-determination and personal as well as sexual integrity, suggesting that the legislation on rape acknowledges that the autonomy of the victim is sometimes violated/threatened/weakened. What we do wish to discuss briefly below is the idea of autonomy in relation to situations other than the three mentioned here and those

102 Estrich, Real Rape (Harvard University Press 1987) and Bohner, Eyssel, Siebler \& Viki, Rape myth acceptance: Cognitive, affective and behavioural effects of beliefs that blame victim and exonerate the perpetrator in Rape: Challenging Contemporary Thinking, eds. Horvath and Brown (Willan Publishing 2009) pp. 17-45.

103 Polismyndigheten och Åklagarmyndigheten, Våldsbrott $i$ när relationer och sexualbrott mot vuxna -En gemensam granskning av polisens och åklagarens handläggning (2019), see also Brottsförebyggande rådet, Våldtäkt från anmälan till dom. En studie av rättsväsendets arbete med våldtäktsärenden (2019).

104 BRÅ (2020).

105 For a discussion on the liberal subject in criminal law, see for example Andersson 2004, Burman 2011, Lacey, Unspeakable Subjects. Feminist essays on legal and societal theory (Hardt Publishing 1998). 
who are included in the criminal offence of rape. There are many situations between the voluntary and the non-voluntary which is mentioned as an exception in paragraph 1-3, where a person does not have access to full autonomy. We hold that this is a grey area, where the autonomy of a person, i.e. the possibility of using one's right to selfdetermination is delimited, in one way or another, due to for example capabilities or unequal relations. ${ }^{106}$ Some of these situations might fall within the scope of the offence of rape, in a particular case, some of them might be included in other sexual offences, and other situations might fall outside the scope of sexual offences. We do not argue that all these situations should be included as part of the offence of rape, but want to highlight and problematise some of the consequences of a legal construction of rape based on non-voluntariness that builds on an idea of the liberal subject.

As follows with the examples given above from discussions in the preparatory work, the Government recognised some of these grey areas, and addresses structural perspectives in part, for example in the discussion on cases when the victim entered a state of frozen fright or did not actually want to participate but decided to do so anyway. In the end, the Government fell back on the liberal idea of the autonomous subject, stating that if a person chose to participate in sexual activities against her will, and the perpetrator did not use force or exploit the victim's vulnerable situation, the act is legal.

\section{Rethinking voluntariness - autonomy and beyond}

\subsection{Introduction}

In this section we will make some reflections and comments on the new construction of rape and point to some examples in the preparatory works that call for further analysis on the requisite of voluntariness and the idea of autonomy that the legislation builds upon. We use an everyday-life perspective which relates to a theoretical concept, lived autonomy, that we will develop in an upcoming article. We start by introducing an everyday life perspective and then apply the perspective to some concrete examples that we draw from the legislative process.

106 This can be discussed in relation to the capabilities that Nussbaum argues should be supported in all democracies, see Nussbaum, Kvinnors liv och social rättvisa: ett försvar för universella värden (Daidalos 2002). 


\subsection{Our theoretical starting points}

We take our point of departure in critique on the law as a detached and closed system, that at the same time claims to define and mirror the social world with legal concepts, criteria and the right methods. ${ }^{107}$ MacKinnon argues that the legal inability to define legal reality in terms of social reality serves as one explanation for the challenges in court. ${ }^{108}$ Naffine has also addressed the problem of not taking women's everyday lives as the point of departure in discussions of rape, by questioning why the harm caused by rape is described in abstract terms instead of women's lived experiences. ${ }^{109}$

Legal research in women's law has traditionally taken its point of departure in women's lives and experiences, but 'everyday life' as a theoretical analytical concept was introduced by Svedberg in 2013 showing how an everyday life perspective can be used in legal research. ${ }^{110}$

She points out that this concept is useful also in legal research where it is applicable, statutory regulation should therefore take its starting point in people's living conditions, in order to be able to obtain gender equality. ${ }^{111}$ The everyday life perspective suggests that we must leave the liberal (white, middle-class, western, male) idea of the autonomous subject behind in order to be able to offer women protection, to secure the right to personal and sexual integrity and sexual self-determination. ${ }^{112}$ Instead we must take our point of departure in women's everyday lives and, hence, anchored in the social world. This implies an understanding of voluntariness, e.g. the ability to say 'yes' and 'no', that depends on the situation the person is part of. It should be noted that the concept of an everyday life perspective in law does not take its point of departure in the individual, but in a structural perspective. In this sense, it is appropriate to explore structural challenges pointed out by previous feminist research. This approach embraces the power relationships, and implies that an individual's autonomy can both increase and decrease in the situational and relational context. ${ }^{113}$

107 See for example MacKinnon 2016; Naffine 2009; Smart, Feminism and the power of law (Routledge 1989); Bladini 2013; Svedberg 2013, Björling, Rättstillämpningens tystnad. En rättsvetenskaplig narratologisk studie om argumentation och rättsliga uttryck inom civilprocessen (Juridiska institutionens skriftserie 2017).

108 MacKinnon 2016.

$109 \quad$ Naffine 2009.

110 Svedberg 2013.

$111 \quad$ Ibid. p. 54.

112 Compare Nedelsky 2011, especially chapter 5.

113 The idea of elasticity in relation to autonomy is not alien in law. One example is the Sales of Goods Act, which requires the buyer to have fulfilled her obligation to examine the item for sale in order to be able to later on make a complaint if the goods are defective. This obligation may be extensive or reduced depending on the circumstances at the time of purchase. 


\subsection{Examples of challenges due to an everyday life perspective}

So, let us now examine the new legal construction of rape through the lens of an everyday life perspective, which is founded in lived experiences and aims at strengthening the ability to define legal reality in terms of lived reality. The decisive criterion of rape is now voluntary participation in sexual intercourse. The prerequisite of voluntariness will be at the centre of the analysis. The further discussion/analysis will also touch upon the interests protected by the legislation, i.e. the (women's) right to personal and sexual integrity as well as a right to sexual self-determination.

Previous feminist critique has pointed to the gap between the abstract legal concepts and the lived reality that the law is supposed to regulate, and underlined the importance of including women's everyday life experiences in the legislative process on rape. ${ }^{114}$ Therefore, with this new rape legislation based on voluntariness that aims at strengthening women's personal and sexual integrity and sexual self-determination is a result of hard work from women's lobbying in mind, we wish to return to the questions that we posed in the introduction. The question is which assumptions are made about what the interests to protect are (and are not) and the second, how they are best protected. With the previous critique as a backdrop, we answer these questions from an everyday life perspective. We look into whose knowledge and whose experiences that are used in the legislative process and what it means for those who are supposed to be protected by the law.

\section{Inner will and passivity}

The first example we wish to highlight is the discussion on the prerequisite of voluntariness in relation to inner will and passivity. One interesting aspect in the preparatory works that we wish to draw attention to is the way inner will is dealt with. A situation where a person does not wish to participate in a sexual act but has explicitly agreed to participate despite the fact that she does not really want to, does not constitute rape. ${ }^{115}$ It should be mentioned that the determining factor suggested in the preparatory works is whether she was able to make a free decision or not. Examples given of situations where a free decision cannot be made are equated to the exceptions made in the third sentence (use of force, threats or exploitation of a vulnerable situation), or in situations when the victim was caught off guard (by a doctor at a medical examination or by a stranger at a festival.). ${ }^{116}$ Additionally, it was pointed out that pressure or persuasion that leads to consent does not constitute rape. The Government argued that the choice to do something that someone wishes to avoid is part of someone's sexual self-determination. This example is clearly an expression of traditional autonomy, and we argue that it is made by a male rationale. We wish to emphasise that the arguments could be turned around. The right not

\footnotetext{
114 See for example MacKinnon 2016 and Naffine 2009.

115 Prop. (2017/18:177) p. 78.

116 Prop. (2017/18:177).
} 
to participate if that is in line with the victim's inner will, i.e. to have access to and be able to uphold the inner will despite pressure and social norms is an important part of the path towards a strengthened protection of women's right to sexual selfdetermination. This would better protect women's right to sexual self-determination from the experiences of women's everyday lives. ${ }^{17}$

The initial suggestion of the legal construction of rape was to include not only the prerequisite of voluntariness, but also a requirement of an expression of voluntariness. This would clearly express the responsibility for the instigating party to ensure that the other person was participating voluntarily, and the normative message would be that the sexual intercourse must be a mutual act. This suggestion was rejected and changed into the assessment prerequisite, i.e. the criterion to clarify the assessment of the voluntariness through expressions of voluntary participation. Note that there is no requirement for such expression, which means that passive participation could also constitute voluntary participation. ${ }^{118}$ This was also argued to be a part of sexual self-determination, to decide how to express the voluntariness, including doing so by passivity. However, the committee seems to have taken a lived autonomy perspective ${ }^{119}$ and highlighted that such allowance of passivity would risk growing prejudice about female sexual passivity and also make it hard to differ from frozen fright, illness or drunkenness. ${ }^{120}$

\section{Intercourse or similar acts with a sleeping spouse/partner}

The second example is arguments on intercourse or similar acts with a sleeping spouse/ partner in relation to a discussion on the draft version of the exceptions in the third sentence, as illustrated above in chapter 3 . The draft formulation concerning the three situations when voluntariness is void, started as: 'an expressed choice to participate in sexual intercourse is not voluntary if [...]'. The aim was to strengthen the protection of sexual integrity, but the committee found it contradictory to include sleep and unconsciousness under paragraph 2 if it related to an expressed will and decided to omit these situations. ${ }^{121}$ In addition, and this is perhaps the most interesting part of this discussion, the committee held that to perform a sexual act with a sleeping partner should not always constitute rape and referred to close relationships where this could occur. We would like to argue that this line of argument seems to be primarily made from a male perspective, or men's everyday life, rather than from that of the women whose sexual integrity the regulation aims to protect.

\footnotetext{
$117 \quad$ See for example Munro 2015.

118 Prop. (2017/18:177) p. 80.

119 The discussion on voluntariness from an everyday life perspective is, as mentioned in the introduction to this section, closely linked to the wider concept of autonomy. We argue that different understandings of autonomy are important analytical tools in a discussion on rape legislation. We suggest an understanding of autonomy as a lived autonomy.

120 SOU (2016:60).

121 Prop. (2017/18:177).
} 
The relationship between rape and the prohibition of purchase of sexual services The third example concerns the relation between the two offences, rape and the prohibition of purchase of sexual services, both regulated in Chapter 6 of the SCC. We argue that these offences overlap, to a greater degree than what is recognised in the preparatory works and in application of the law. It could also be mentioned that the offence of purchase of sexual services is complementary to the offence of rape, even if they are mainly discussed in different terms when it comes to the interests to be protected by the legislation. The prohibition of purchase of sexual services mainly addresses public order as an important interest to be protected, and the victim is not regularly part in the process, and hence lacks the right to legal counsel in these cases, even if the lawmakers recognise the risk of the seller being in a vulnerable situation. ${ }^{122}$ This analysis is partly of a different character and could be the subject of an article on its own, but we will just address it briefly here and pose some questions concerning the view of autonomy that might be revealed behind the two offences. We will also make some general comments on the lack of a common ground for these two offences, especially in terms of autonomy. In the preparatory works for the new rape legislation the relationship between these two crimes is only mentioned in the situation when the seller is also a victim of trafficking and this is a fact that the buyer should know about. Read conversely, this should mean that all other situations fall outside the scope of the legislation, as long as the sexual act has not exceeded the limits of violence agreed upon. Such an interpretation builds on the idea of going into prostitution being a free choice in all other situations, or at least not a particularly vulnerable situation, a result of the traditional view of autonomy. We argue, by taking our point of departure in the everyday lives of the women who have been active in prostitution, that prostitution is (almost) never a free choice made by a person through her traditional autonomy but is a result of trauma after previous experiences of sexual violence, mental illness, poverty or other severe vulnerable situations. ${ }^{123}$ Yet this is not recognised in the preparatory work for the new rape legislation. Another aspect of autonomy that should be mentioned here is that sexual autonomy is supposed to be protected by the offence of rape, whereas it seems to be another conception of autonomy prevailing in the context of purchasing sexual services. In such cases will economic interests and an economic rationale trump the violation of the personal and sexual integrity committed by the non-voluntary sexual act. ${ }^{124}$ The economic gain hence compensates for the injuries to body and soul and can be read as an expression of the (male) division of human beings into body and mind, where the mind prevails,

122 Prop. (2017/18:177).

123 See \#intedinhora at intedinhora.se for testimonies on how and why these women ended up in prostitution. \#Intedinhora is a network of Swedish women with experience of commercial sexual exploitation and their work aims to stop people from being exploited in prostitution.

124 In this article we do not discuss the fact that women in prostitution have a much harder time claiming their rights in a rape case, which is a very important aspect of the application of the legislation, but at the periphery of the discussion here. Although we recommend the reader to see Bitsch 2019 for such an analysis. 
and the body is made invisible or just neglected. This is closely linked to Lacey's discussion on the legislative conception of free will, where she argues that bodily and emotional aspects of sexual crimes are placed in the background and the intellectual aspects in the foreground as an effect of this separation of body and mind. ${ }^{125}$

\section{Concluding comments}

In this article we have set Swedish rape legislation in a historical context and presented some of the main arguments put forward by feminist legal scholars. As we have seen, some of these points of critique have been responded to through the various reforms. In recent times the most important change has been the shift in which responsibility for the rape is moved from the victim to the perpetrator. This is a great step forward as it sends a strong normative message that a woman's body is unavailable until she says 'yes'.

The main points of critique that are still relevant can be summarised as an inability in law itself to deal with vulnerabilities, structural power imbalances and various forms of situations where the victim cannot use her capability to express her will due to a demarcated autonomy in the specific time- and spatial-bound context. Although some of these problems were addressed in the preparatory works, it is obvious that they still remain unsolved. Although the interests to protect, the right to personal and sexual integrity and sexual self-determination, are founded in lived reality, there is still a gap in relation to the legal construction. The legal construction takes its point of departure in the prerequisite of voluntariness and builds on the idea of two equal parties in accordance with the liberal idea of autonomy, although there are certain exceptions. The gap between the legal construction and lived reality can partly be explained by the male rationale that has influenced the legal construction and the everyday life that the construction builds upon.

When prohibition of purchase of sexual services was introduced, it was exceptional, because Sweden was the first country to only criminalise the buyer's action. Today, we have come a long way, by introducing voluntary-based rape legislation. We argue that this new legislation of rape means that the offence of purchase of sexual services must be seen in a completely new light. One effect of not having recognised the entanglement between these two offences is that men can buy their way out of criminal responsibility for 'rape'. Therefore, one important research question to scrutinise in more depth in the immediate future is this entanglement as well as the assumptions made on the differences between the two offences.

This review of the previous, as well as the new, rape legislation strengthens our view that there is a need for more depth studies of the rape legislation and the application 
of it. We hold that the requisite of voluntariness on the one hand is a great step forward for feminist legal work, as described in the second section. On the other hand, the requisite raises great challenges when it comes to 1) the fact that men's knowledge and experiences permeates the preparatory work, 2) this in turn, constitutes a problem in the application of the rape legislation because the preparatory works is the most important legal source, and 3) one effect in practice, of the male rationale within the legislation, is that women as a group, at least not all women, get access to the protection that the new rape legislation is supposed to offer them.

The question of voluntariness is closely linked to the subject and her autonomy. Therefore we argue that different understandings of autonomy are important analytical tools in further research on rape legislation. We suggest an introduction and development of the understanding of autonomy as a lived autonomy, based on an everyday life perspective, due to its potential as an analytical concept in analyses of legislation processes, as well as of application of the law. In a feminist context, and in general, the concept is useful if and when one wishes to search for patterns, in this case assess whether the new regulation in fact protects his or her personal and sexual integrity and sexual self-determination. Not all flowers can grow and evolve in the same way irrespective of soil and climatic conditions. ${ }^{126}$

126 We symbolise lived autonomy as a flower, to underline the lived aspect (from the everyday life perspective), where each petal illustrates how autonomy is constantly in change, and thus showing that the individual's autonomy is elastic. The expansion of the autonomy or demarcation of the same is illustrated by the length of the petals. A person's autonomy can be reduced or expanded over time due to the relational and situational context and depends on an infinite variation of factors, coercive circumstances and vulnerability included. A person's autonomy also varies through life: a youth has a delimited autonomy compared to an adult. 